\title{
Significant decrease in yield under future climate conditions: Stability and production of 138 spring barley accessions
}

\author{
Cathrine Heinz Ingvordsen ${ }^{a, *}$, Gunter Backes ${ }^{b}$, Michael Foged Lyngkjær ${ }^{c}$, \\ Pirjo Peltonen-Sainio ${ }^{\mathrm{d}}$, Jens Due Jensen ${ }^{\mathrm{e}}$, Marja Jalli ${ }^{\mathrm{d}}$, Ahmed Jahoor ${ }^{\mathrm{e}}$, \\ Morten Rasmussen ${ }^{\mathrm{f}}$, Teis Nørgaard Mikkelsen ${ }^{\mathrm{a}}$, Anders Stockmarr ${ }^{\mathrm{g}}$, \\ Rikke Bagger Jørgensen ${ }^{\mathrm{a}}$
}

\author{
a Centre for Ecosystems and Environmental Sustainability, Department of Chemical and Biochemical Engineering, Technical University of Denmark, \\ Frederiksborgvej 399, Roskilde DK-4000, Denmark \\ ${ }^{\mathrm{b}}$ University of Kassel, Faculty of Organic Agricultural Sciences, Section of Organic Plant Breeding and Agrobiodiversity, Nordbahnhofstr. 1a, \\ Witzenhausen D-37213 Germany \\ ' University of Copenhagen, Department of Plant and Environmental Sciences, Thorvaldsensvej 40, Frederiksberg C DK-1871, Denmark \\ d MTT Agrifood Research Finland, Plant Production Research, Tietotie, Jokioinen FI-31600 Finland \\ e Nordic Seed A/S, Kornmarken 1, Galten DK-8464, Denmark \\ ${ }^{\mathrm{f}}$ Nordic Genetic Resource Center, Smedievägen 3, Alnarp SE-230 53, Sweden \\ $\mathrm{g}$ Section for Statistics and Data Analysis, Department of Applied Mathematics and Computer Science, Technical University of Denmark, Richard Petersens \\ Plads, Kgs. Lyngby DK-2800, Denmark
}

\section{A R T I C L E I N F O}

\section{Article history:}

Received 8 April 2014

Received in revised form

27 November 2014

Accepted 1 December 2014

\section{Keywords:}

Carbon dioxide

Carbon dioxide exploitation

Climate change

Combined treatment

Hordeum vulgare

Phenotypes

Production parameters

Ozone

Temperature

\begin{abstract}
A B S T R A C T
The response in production parameters to projected future levels of temperature, atmospheric carbon dioxide $\left(\left[\mathrm{CO}_{2}\right]\right)$, and ozone $\left(\left[\mathrm{O}_{3}\right]\right)$ was investigated in 138 spring barley accessions. The comprehensive set of landraces, cultivars, and breeder-lines, were during their entire life cycle exposed to a two-factor treatment of combined elevated temperature $\left(+5^{\circ} \mathrm{C}\right.$ day/night $)$ and $\left[\mathrm{CO}_{2}\right](700 \mathrm{ppm})$, as well as single-factor treatments of elevated temperature $\left(+5^{\circ} \mathrm{C}\right.$ day/night $),\left[\mathrm{CO}_{2}\right](700 \mathrm{ppm})$, and $\left[\mathrm{O}_{3}\right](100-150 \mathrm{ppb})$. The control treatment was equivalent to present average South Scandinavian climate (temperature: $19 / 12^{\circ} \mathrm{C}$ (day/night), $\left[\mathrm{CO}_{2}\right]: 385 \mathrm{ppm}$ ). Overall grain yield was found to decrease $29 \%$ in the two-factor treatment with concurrent elevation of $\left[\mathrm{CO}_{2}\right]$ and temperature, and this response could not be predicted from the results of treatments with elevated $\left[\mathrm{CO}_{2}\right]$ and temperature as single factors, where grain yield increased $16 \%$ and decreased $56 \%$, respectively. Elevated $\left[\mathrm{O}_{3}\right]$ was found to decrease grain yield by $15 \%$. Substantial variation in response to the applied climate treatments was found between the accessions. The results revealed landraces, cultivars, and breeder-lines with phenotypes applicable for breeding towards stable and high yield under future climate conditions. Further, we suggest identifying resources for breeding under multifactor climate conditions, as single-factor treatments did not accurately forecast the response, when factors were combined.
\end{abstract}

(c) 2014 Elsevier B.V. All rights reserved.

\section{Introduction}

Climate change alters growth environments around the world and challenges agricultural production. At the same time the world

\footnotetext{
* Corresponding author. Tel.: +45 28511905; fax: +45 45882258.

E-mail addresses: cahi@kt.dtu.dk (C.H. Ingvordsen), gbackes@uni-kassel.de (G. Backes), mlyn@plen.ku.dk (M.F. Lyngkjær), pirjo.peltonen-sainio@mtt.fi (P. Peltonen-Sainio), jdje@nordicseed.com (J.D. Jensen), marja.jalli@mtt.fi (M. Jalli), jah@nordicseed.com (A. Jahoor), morten.rasmussen@nordgen.org (M. Rasmussen), temi@kt.dtu.dk (T.N. Mikkelsen), anst@dtu.dk (A. Stockmarr), rijq@kt.dtu.dk (R.B. Jørgensen).
}

population is growing with the need of an increased food production. Unprecedented climate conditions are reported to occur around 2047 (+/- 14 years; Mora et al., 2013), and already by now actual levels of temperature, and atmospheric concentration of the abundant greenhouse gasses carbon dioxide $\left(\left[\mathrm{CO}_{2}\right] ; 400 \mathrm{ppm}\right)$ and ozone ( $\left[\mathrm{O}_{3}\right]$; 32-62 ppb) have affected yields of cereals (Lobell and Field, 2007; Lobell et al., 2011; Trnka et al., 2012; Ellermann et al., 2013). Elevated temperature has been found to decrease crop yield e.g., by closing of stomata thus avoiding transpiration, but at the same time inhibiting photosynthesis and thereby disrupting anthesis and grain formation (Barnabás et al., 2008). The negative effect of elevated temperature is possibly reduced by increased $\left[\mathrm{CO}_{2}\right]$ boost- 
ing photosynthesis (Long et al., 2006). Ozone is highly reactive and can lead to reactive oxygen species detrimental to the photosynthetic apparatus (Fuhrer and Booker, 2003).

By the end of the 21st century temperature is expected to increase by $3-5^{\circ} \mathrm{C}$ according to the worst-case scenario (RCP8.5) of IPCC (Collins et al., 2013). The [ $\left[\mathrm{CO}_{2}\right]$ is to reach $1415-1910 \mathrm{ppm}$ and $\left[\mathrm{O}_{3}\right]$ to increase by $25 \%$ compared to the concentrations experienced today (32-62 ppb). The latest assessment report of IPCC, working group I, also considered three other climate scenarios with lower increase in the anthropogenic emission of greenhouse gases leading to less elevated temperature, however, a recent study suggests that the RCP8.5 worst-case scenario very probably is the one to expect (Sherwood et al., 2014). Along with climate change follows increase in frequency of extreme events such as floods, heatwaves, droughts, and storms with great risk of additional threat to future agricultural production (Collins et al., 2013; IPCC, 2014). The rapid changes in growth conditions induced by altered climatic conditions enhance the need to develop climate resilient cultivars and apply new management practices (Anwar et al., 2013).

The annual growth rate of the global agricultural production was on average $2.1 \%$ from 2003 to 2012, however, it is expected to decrease to $1.5 \%$ per year in the coming decades (OECD/FAO, 2013). The lower growth rate is due to limited expansion of agricultural land, rising production costs, restricted use of non-renewable resources together with reduced use of fertilizer, and pest control agents to limit their environmental side effects (Foley et al., 2011; OECD/FAO, 2013). Plant breeding has the enormous task to increase future primary production. In this context, gene bank material and exotic accessions can possess traits to be exploited in the development of stable and high yielding climate resilient cultivars. An obstacle to the use of these resources is the limited information on climate tolerance of plant accessions (Ceccarelli et al., 2010; Newton et al., 2011). Also the methodical complexity in the search for tolerance to conditions not earlier experienced by any crop is challenging. As emphasized by Powell et al. (2012), the utilization of genetic resources with tolerance to climate factors is impeded by lack of reliable and cost efficient screening methods.

Considerable knowledge on climate change effects to crops are still needed to plan best breeding strategies to secure the production. For example the following two topics have received little attention: Climate change has been found to affect various crop species differently (e.g., Feng and Kobayashi, 2009; Kimball, 1986; Luo, 2011; Mills et al., 2007), however, the intraspecific variation - between and within accessions - in response to changes has received little focus (e.g., Craufurd et al., 2003; Pleijel, 2011; Weigel and Manderscheid, 2012). Also, in studies of climate change effects on crop accessions, rather few have investigated the effects of treatments, where more than one climate factor was changed (Alemayehu et al., 2014; Clausen et al., 2011; Frenck et al., 2011; Juknys et al., 2011; Kasurinen et al., 2012; Mitchell et al., 1993; Zhou et al., 2011).

In the Nordic countries, around half of the cultivated area (9 million ha) is used for growing cereals and in 2012 barley (Hordeum vulgare L.) was the main cereal (FAOSTAT, 2014). Also in the EU barley is an important crop cultivated on $21 \%$ of the cereal crop area (European Union, 2014). The grains are used for malt and feed, however, the yield is stagnating (FAOSTAT, 2014). Under mid to high latitude conditions a temperature increase exceeding $2{ }^{\circ} \mathrm{C}$ is expected to reduce cereal yields (IPCC, 2014). The Nordic agriculture is further in risk of summer drought and heavy rains with changes in precipitation patterns leading to decreased grain yield (Christensen et al., 2011; Högy et al., 2013).

In this study, the effects of elevated temperature and the most abundant greenhouse gasses, $\mathrm{CO}_{2}$ and $\mathrm{O}_{3}$ were analyzed on 138 spring barley accessions. The climate treatments were applied over the entire crop life cycle as single- and two-factor (elevated tem- perature and $\left[\mathrm{CO}_{2}\right]$ ) treatments. Accessions with phenotypes that could alleviate or inhibit effects of future climate change on grain yield and harvest stability were identified.

\section{Material and methods}

\subsection{Plant material}

The spring barley material tested consisted of 48 landraces, 32 old cultivars (1883-1974), 53 modern cultivars (1978-2013), and 5 breeder-lines. The majority of the accessions had Nordic origin, viz. Denmark, Sweden, Norway, and Finland. Eight of the modern cultivars and 22 of the landraces had non-Nordic origin (e.g., Afghanistan, Belgium, Croatia, France, Germany) and 8 accessions had unknown origin (Appendix A). Modern cultivars and breeder-lines were supplied by the Nordic breeders in the network 'Sustainable primary production in a changing climate' (NordForsk) and a few cultivars were from the BAR-OF project (ICROFS, Denmark). All other accessions were supplied by the Nordic Genetic Resource Center (NordGen; http://www.nordgen.org/).

\subsection{RERAF, technical description}

All plants were cultivated in the RERAF phytotron (Risø Environmental Risk Assessment Facility) at the Technical University of Denmark. RERAF has six identical physically separated gas-tight chambers (width $6 \mathrm{~m}$, depth $4 \mathrm{~m}$ and height $3 \mathrm{~m}$ ). The chambers had individual control of light, temperature, humidity, and gasses (chamber atmospheres) and with continuous monitoring of all parameters. Air mixing within chambers was ensured by two wind turbines placed on opposite sides. Humidity was generated by a humidifier (HumiDisk 65, Carel) placed in front of one of the wind turbines. The light was supplied by 28 high-pressure mercury ( $1000 \mathrm{~W}$ or $400 \mathrm{~W})$ and 14 halogen $(250 \mathrm{~W})$ lamps per chamber. The lamps could be turned on or off individually, which was used to simulate sunrise and sunset. The $\left[\mathrm{CO}_{2}\right]$ was supplied by Air Liquide Denmark $\mathrm{A} / \mathrm{S}$ and the application controlled according to the continuous measurements. The $\left[\mathrm{O}_{3}\right]$ in the chambers was supplied by UV Pro 550 A (Crystal air products \& services, Canada) generators, which were manually adjusted. Further details on RERAF are given by Alemayehu et al. (2014) and Frenck et al. (2011).

\subsection{Growth conditions}

Pots with a volume of $11 \mathrm{~L}$ were filled with $4 \mathrm{~kg}$ of sphagnum substrate (Pindstrup Substrate No. 6, Pindstrup Mosebrug A/S, Denmark) supplemented with $10 \mathrm{~g}$ NPK fertilizer (21-3-10, Yara). Twelve seeds of each accession were sown and seedlings thinned to eight plants per pot per treatment. The pots were placed on wheeled plant-tables, and plants were grown for their entire lifecycle in RERAF with different levels of temperature, $\left[\mathrm{CO}_{2}\right]$ and $\left[\mathrm{O}_{3}\right]$. Water supply was identical in all treatments and above the average precipitation of Southern Scandinavia to compensate for loss of water, root distribution and drainage dictated by the pot setup. Watering was carried out by a surface dripping system that delivered $4.4 \mathrm{~L} \mathrm{~m}^{-2}$ day $^{-1}$ at the beginning of the daytime regime. When $2 / 3$ of the accessions had begun ripening at Zadoks Growth Stage (ZGS) 90, watering was reduced in a stepwise fashion and ended at maturity corresponding to ZGS 99 (Zadoks et al., 1974). All treatments had identical light and humidity conditions. The light regime was PAR (parabolic aluminized reflector) averaged at approximately $400 \mathrm{~mol}$ photons $\mathrm{m}^{-2} \mathrm{~s}^{-1}$ at canopy height (ca. $1 \mathrm{~m}$ ), and a daily cycle of $16 / 8 \mathrm{~h}$ (day/night) with simulated sunrise and sunset within the first and last hour of the light regime. The humidity was 55/70\% (day/night). To avoid biases of chambers, 
Table 1

Set point-values and experimental levels of the abiotic factors applied in the treatments.

\begin{tabular}{|c|c|c|c|c|c|c|c|c|}
\hline \multirow[t]{2}{*}{ Treatment } & \multicolumn{2}{|c|}{ Temperature, ${ }^{\circ} \mathrm{C}$ (day/night) } & \multicolumn{2}{|c|}{$\left[\mathrm{CO}_{2}\right], \mathrm{ppm}$} & \multicolumn{2}{|l|}{$\left[\mathrm{O}_{3}\right], \mathrm{ppb}$} & \multicolumn{2}{|c|}{ Humidity, \% (day/night) } \\
\hline & Set point & Experimental & Set point & Experimental & Set point & Experimental & Set point & Experimental \\
\hline Ambient & $19 / 12$ & $18.9 \pm 1.2 / 11.8 \pm 0.8$ & 385 & $448.5 \pm 81.1$ & 0 & $1.4 \pm 1.4$ & $55 / 70$ & $55.7 \pm 2.5 / 69.9 \pm 1.5$ \\
\hline$+\mathrm{CO}_{2}$ & $19 / 12$ & $19.0 \pm 1.2 / 12.5 \pm 2.1$ & 700 & $684.7 \pm 41.1$ & 0 & $0.1 \pm 1.7$ & $55 / 70$ & $55.3 \pm 5.1 / 69.4 \pm 5.9$ \\
\hline+ tmp & $24 / 17$ & $23.9 \pm 1.4 / 16.8 \pm 0.8$ & 385 & $448.4 \pm 74.4$ & 0 & $1.9 \pm 1.2$ & $55 / 70$ & $55.9 \pm 2.8 / 69.8 \pm 1.6$ \\
\hline+ tmp and $\mathrm{CO}_{2}$ & $24 / 17$ & $23.8 \pm 1.3 / 16.9 \pm 0.9$ & 700 & $688.3 \pm 38.2$ & 0 & $1.5 \pm 1.4$ & $55 / 70$ & $56.0 \pm 2.9 / 69.8 \pm 1.8$ \\
\hline$+\mathrm{O}_{3}$ & $19 / 12$ & $18.9 \pm 1.2 / 11.9 \pm 1.0$ & 385 & $443.1 \pm 67.5$ & $100-150 \mathrm{ppb}$ & $121.1 \pm 32.8$ & $55 / 70$ & $55.7 \pm 2.4 / 69.8 \pm 1.7$ \\
\hline
\end{tabular}

the plants were rotated weekly both between and within the chambers. In practice, all chambers were set to ambient conditions before rotation; when ambient conditions were reached, the plants were moved into a new chamber and the corresponding treatment was continued. The set points of the treatments were reached within $1 \mathrm{~h}$. Rotation was omitted after 97 days, as plants were too tall to be moved between chambers without damage to the plant material. At any given time, the positions of the accessions were identical between treatments.

The treatments applied in RERAF consisted of four climate treatments and one control treatment (Table 1). Set points of the ambient control treatment mimicked average present South Scandinavian climate in the spring barley growing season with $19 / 12^{\circ} \mathrm{C}$ (day/night) and $385 \mathrm{ppm}\left[\mathrm{CO}_{2}\right]$. In the four climate treatments factors were manipulated to the levels close to those projected at the end of the 21st century (corresponding to a scenario, where greenhouse gasses are emitted in a "business as usual" magnitude ( $\sim$ RCP8.5) and consisted of three single-factor treatments and one two-factor treatment. The three single-factor treatments were: temperature elevated $+5{ }^{\circ} \mathrm{C}$ (day/night), elevated $\left[\mathrm{CO}_{2}\right]$ at $700 \mathrm{ppm}$ and $\left[\mathrm{O}_{3}\right]$ targeted at $100-150 \mathrm{ppb}$. In the two-factor treatment the elevated levels of temperature and $\left[\mathrm{CO}_{2}\right]$ were combined. Ozone was applied above the projected average level since barley has been found to possess high $\mathrm{O}_{3}$-tolerance (Mills et al., 2007). Besides, an $\left[\mathrm{O}_{3}\right]$ at $100-150 \mathrm{ppb}$ can quite often be found locally, where ozone emissions are high (Wei et al., 2014).

\subsection{Production parameters and data treatment}

Plants were harvested individually at maturity and the material from all treatments was dried under identical conditions ( 2 months at $20^{\circ} \mathrm{C}$, continuous high air flow, $55 \%$ relative humidity) before threshing. The production parameters, grain yield, aboveground vegetative biomass, and total number of ears were determined for the individual plants. Harvest index (grain yield relative to total aboveground biomass) was calculated. Number of seeds per plant was obtained from the seed weight per plant divided by the weight of an enumerated sub-sample of 40 grains.

The experimental values of temperature and $\left[\mathrm{CO}_{2}\right]$ were measured and their deviation from set points calculated (Table 1 ). From the measured $\left[\mathrm{O}_{3}\right]$ the accumulated ozone exposure over a threshold of $40 \mathrm{ppb}$ (AOT40) was calculated according to Fuhrer et al. (1997):

AOT $40_{\text {measured }}=\Sigma_{i} \max \left(0,\left(C_{i}-40\right)\right)$

where $C_{i}$ is the hourly mean ozone concentration in ppb averaged over all hourly values measured in the daylight hours (in this case $16 \mathrm{~h}$ ) each day and for the central 90 days of the duration of the experiment.

To investigate potentially additive treatment effects of $\mathrm{CO}_{2}$ and temperature on grain yield (Table 1), a two-way ANOVA with randomized pot effect was applied. The pot effect was investigated through maximum likelihood estimation, which considered potential within-pot-competition effects. The model was corrected for varying yield levels of the individual accessions through the addi- tion of a systematic effect. After establishing a positive within-pot correlation, the analysis was carried out with standard software for mixed effects models. The effect of cultivar's year of registration (at the official variety list) on grain yield was investigated subjected to the different treatments, through a series of regression models with randomized pot effect. A Bonferroni correction was applied to the test evaluation. Boxplots were established on averaged production parameters and significance given to ambient according to $T$-test with ${ }^{* * *} p<0.001 ;{ }^{* *} p<0.01 ;{ }^{*} p<0.05$. All analyses were carried out using the software package R, version 3.10 (R Core Team, 2014).

\subsection{Stability analysis}

A static yield stability index was calculated according to environmental variance $\left(S^{2}\right.$; Roemer, 1917):

$S^{2} i=\frac{\Sigma\left(R_{i j}-m_{i}\right)^{2}}{(e-1)}$

where, $R_{i j}$ is the observed yield of the accession $i$ in the treatment $j$, $m_{i}$ is mean yield of the accession across treatments, and $e$ is number of environments. A dynamic yield stability index was calculated according to Wricke's ecovalence ( $W^{2}$; Wricke, 1962):

$W^{2} i=\Sigma\left(R_{i j}-m_{i}-m_{j}+m\right)^{2}$

where $R_{i j}$ is the observed yield of the accession $i$ in the treatment $j, m_{i}$ is mean yield of the accession across treatments, $m_{\mathrm{j}}$ is mean yield across treatment $j$ of all accession and $m$ is the grand mean, average of all $m_{i}$. Hence, $W^{2}$ states the stability dependent on the pool of accessions studied by taking means of all accessions $\left(m_{j}\right.$ and $m$ ) into account, whereas $S^{2}$ is a function of only the specific accession in question.

\section{Results}

\subsection{Experimental values}

The actual values of temperature, $\left[\mathrm{O}_{3}\right]$ and humidity within the treatments in the RERAF phytotron corresponded to the set points (Table 1). The experimental level of $\left[\mathrm{CO}_{2}\right]$ was increased by $15-16 \%$ compared to the set point of $385 \mathrm{ppm}$, however, the higher experimental values of $\left[\mathrm{CO}_{2}\right]$ were in agreement over all treatments with ambient $\left[\mathrm{CO}_{2}\right]$. The experimental $\left[\mathrm{O}_{3}\right]$ level resulted in an AOT40 of $113 \mathrm{ppb} / \mathrm{h}$.

Plants in the two-factor treatment were the first to reach Zadoks growth stage 99 and watering was ended 104 days after sowing. In the treatment of elevated temperature watering was ended 114 days after sowing; in the ambient and elevated $\left[\mathrm{CO}_{2}\right]$ treatments watering was ended 117 days after sowing and after 120 days in the treatment of elevated $\left[\mathrm{O}_{3}\right]$.

\subsection{Overall treatment effects}

Visually observed effects of the climate treatments on plant phenotypes are shown in Fig. 1. Elevated temperature and $\left[\mathrm{CO}_{2}\right]$ had opposite effects, as temperature decreased and $\left[\mathrm{CO}_{2}\right]$ increased 
a)

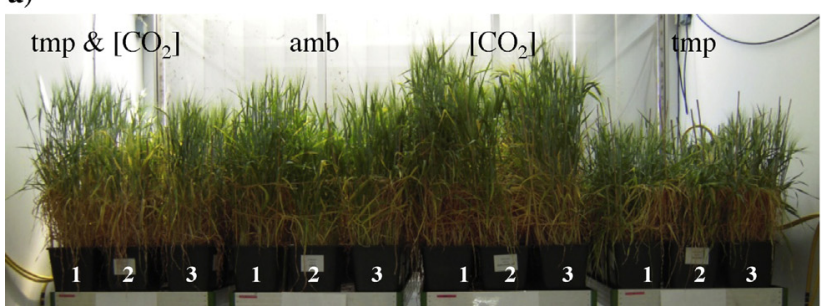

b)

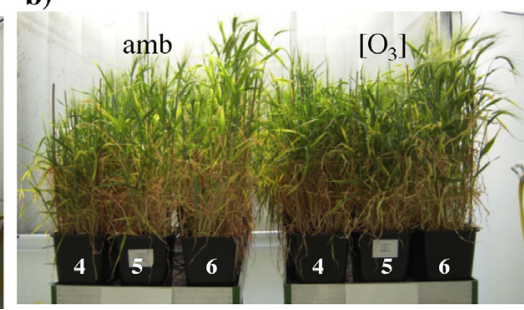

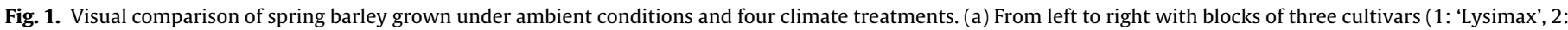

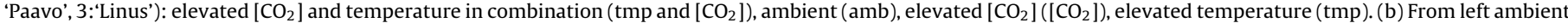
(amb) and elevated $\left[\mathrm{O}_{3}\right]\left(\left[\mathrm{O}_{3}\right]\right)$ with block of three cultivars (4: 'Alf', 5: 'Fløya', 6: ‘Åsa').

height and vigor. In the two-factor treatment with combined elevated temperature and $\left[\mathrm{CO}_{2}\right]$, plant height and vigour were visually similar to those of the ambient treatment, but plants from the combined treatment showed increased developmental rate, as maturity was reached earlier. Elevated $\left[\mathrm{O}_{3}\right]$ caused no visual changes in plant height and vigour (Fig. 1b), but occasionally brown spots were observed.

Overall grain yield (Fig. 2a) was strongly affected by the climate treatments and decreased $28.9 \%$ under the two-factor climate scenario of elevated temperature and $\left[\mathrm{CO}_{2}\right]$. As for the single-factor treatments, elevated temperature decreased overall grain yield by $55.8 \%$ compared to ambient, and elevated $\left[\mathrm{CO}_{2}\right]$ increased the yield by $16.1 \%$. Elevated $\left[\mathrm{O}_{3}\right]$ was found to decrease grain yield by $14.9 \%$, but number of grains declined with only $4.4 \%$. Overall number of grains followed the pattern of grain yield for the different treatments, whereas number of ears was increased for all treatments compared to ambient (data not shown). Overall aboveground veg-
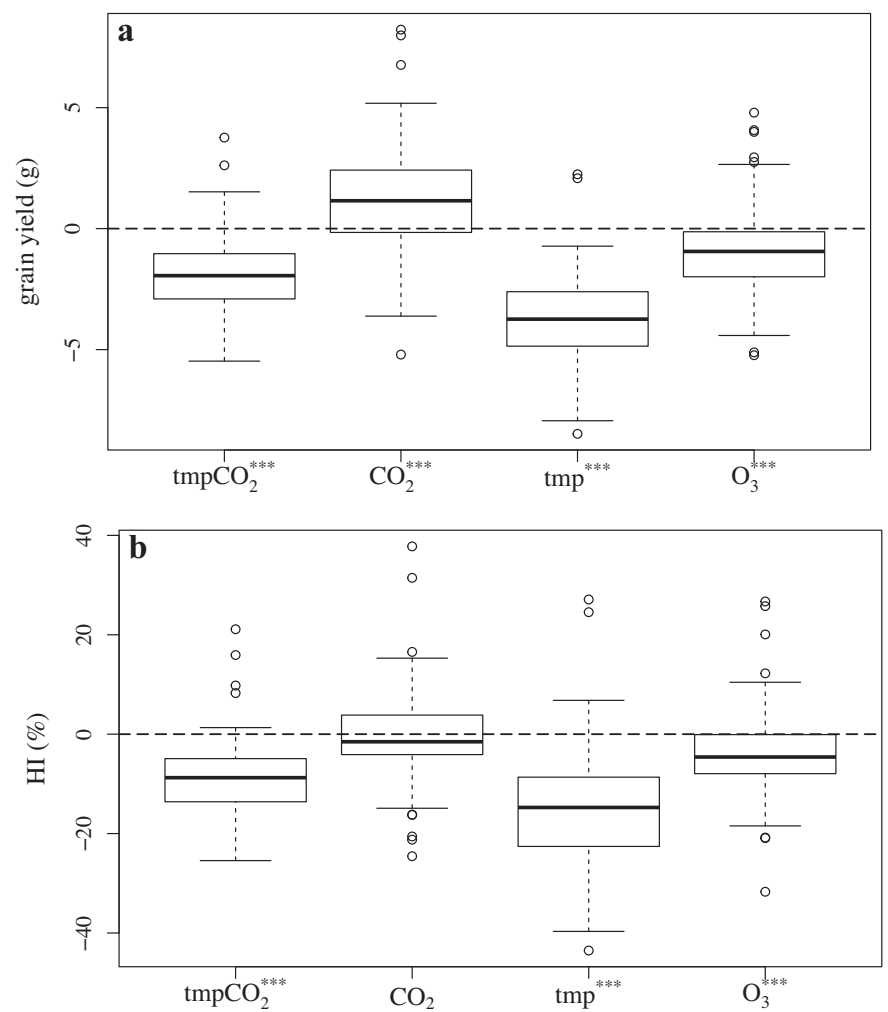

Fig. 2. Overall grain yield (g/plant) a) and $\mathrm{HI}(\%)$ b) of 138 spring barley accessions grown under four climate treatments; elevated temperature and $\left[\mathrm{CO}_{2}\right]\left(\mathrm{tmpCO}_{2}\right)$, elevated $\left[\mathrm{CO}_{2}\right]\left(\mathrm{CO}_{2}\right)$, elevated temperature $(\mathrm{tmp})$ and elevated $\left[\mathrm{O}_{3}\right]\left(\mathrm{O}_{3}\right)$. Dashed line: production in the ambient control treatment $(0)$. Circles represent the average of outlier accessions. Median indicated in bold and whiskers give quartile group 1 and 4. Significance of the treatments to ambient, ${ }^{* * *} p<0.001 ;{ }^{* *} p<0.01 ;{ }^{*} p<0.05$. etative biomass was decreased under elevated temperature and increased by elevated $\left[\mathrm{CO}_{2}\right]$, but not affected by elevated $\left[\mathrm{O}_{3}\right]$ and the two-factor treatment. However, HI was decreased both under elevated $\left[\mathrm{O}_{3}\right]$ and the two-factor treatment (Fig. 2b). Only in the treatment of elevated $\left[\mathrm{CO}_{2}\right]$ was overall $\mathrm{HI}$ unaffected (Fig. 2b).

The applied model rejected an additive effect of elevated $\left[\mathrm{CO}_{2}\right]$ and temperature in their combined treatment $(p<0.0001)$, and found a positive interaction, hence overall grain yield decreased less in the two-factor treatment than could be expected from the production in the single-factor treatments.

Dividing the accessions into groups of cultivars and landraces revealed that the cultivar-group produced more ears in all treatments, except for the two-factor treatment (Table 2). In the $+5^{\circ} \mathrm{C}$ treatment the group of cultivars produced $37.3 \%$ more ears than the group of landraces. An increase of $11.5 \%$ was found from elevated $\left[\mathrm{CO}_{2}\right]$ on overall grain yield of the cultivar-group, but not on aboveground vegetative biomass, when compared to the landrace-group. No statistically significant correlation was found between the grain yield and the year of registration (at the official variety list) of cultivars analysed over all treatments (Bonferroni-corrected, $p=0.18$ ). However, under elevated $\left[\mathrm{CO}_{2}\right]$ a borderline significance $(p=0.46)$ was found between year of registration and grain yield.

The climate effect on grain yield, number of grains, aboveground vegetative biomass and number of ears is illustrated with a heat map for all accessions under all treatments in Appendix B.

\subsection{Accession specific effects}

Substantial variation was found in the response of the accessions, with some of the accessions reacting differently from the overall trend, e.g., with no response to elevated $\left[\mathrm{CO}_{2}\right]$ or increased grain yield under elevated $\left[\mathrm{O}_{3}\right]$. The deviant responses were demonstrated both by landraces and cultivars.

Considering the grain yield response to elevated temperature, $\left[\mathrm{CO}_{2}\right]$ and their combination relative to grain yield under ambient conditions, three accessions, 'Sanglich', 'Lantkorn från Jämtland' and 'Fabel Sejet' showed highly productive in the future climate scenarios, however, they also ranked as the three least productive accessions in the ambient treatment (Fig. 3). Several accessions responded positively to elevated $\left[\mathrm{CO}_{2}\right]$, and the accessions 'Alliot', 'Brage', 'Fairytale', 'Gunnar', 'Jacinta', 'Manschurei', and 'Odin' increased grain yield more than $50 \%$ (Fig. 3) in this treatment. In the treatment of elevated temperature, which decreased overall grain yield considerably, 'Evergreen', 'Fræg', 'Königsberg', 'Luusua', 'Odin', 'Sebastian', and 'Sort Glatstakket' demonstrated less than $30 \%$ decrease (Fig. 3). In the two-factor treatment, the most realistic future scenario applied, accessions demonstrating less than $10 \%$ reduced grain yield compared to the identified overall effect were identified. They were 'Alliot', 'Justus', 'Bor05135', 'Brage', 'Brio', ‘Fairytale', 'Griechische', ‘Gunnar', 'Jacinta', 'Kushteki', 'Lysimax', 'Moscou', 'NOS 17009-53', ‘Calisi', 'Oslo', 'Sebastian', and 'Sort Glatstakket' (Fig. 3). 
Table 2

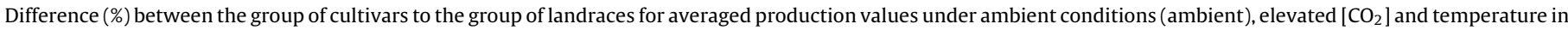

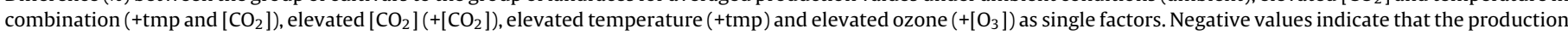
of the cultivar group is less than that of the landrace group.

\begin{tabular}{|c|c|c|c|c|c|}
\hline & Ambient & + tmp and $\left[\mathrm{CO}_{2}\right]$ & $+\left[\mathrm{CO}_{2}\right]$ & + tmp & $+\left[\mathrm{O}_{3}\right]$ \\
\hline No of ears & $19.7^{* *}$ & 7.4 & $23.7^{* * *}$ & $37.3^{* * *}$ & $23.5^{* * *}$ \\
\hline Grain yield & 4.0 & 2.9 & $11.5^{*}$ & 13.3 & 3.5 \\
\hline Aboveground vegetative biomass & -5.0 & -6.6 & -3.0 & 9.5 & -5.0 \\
\hline No of grains & -4.8 & -6.6 & -2.5 & 4.5 & -5.3 \\
\hline
\end{tabular}

Significances: ${ }^{* * *} 0.001 ;{ }^{* *} 0.01 ;{ }^{*} 0.05$.

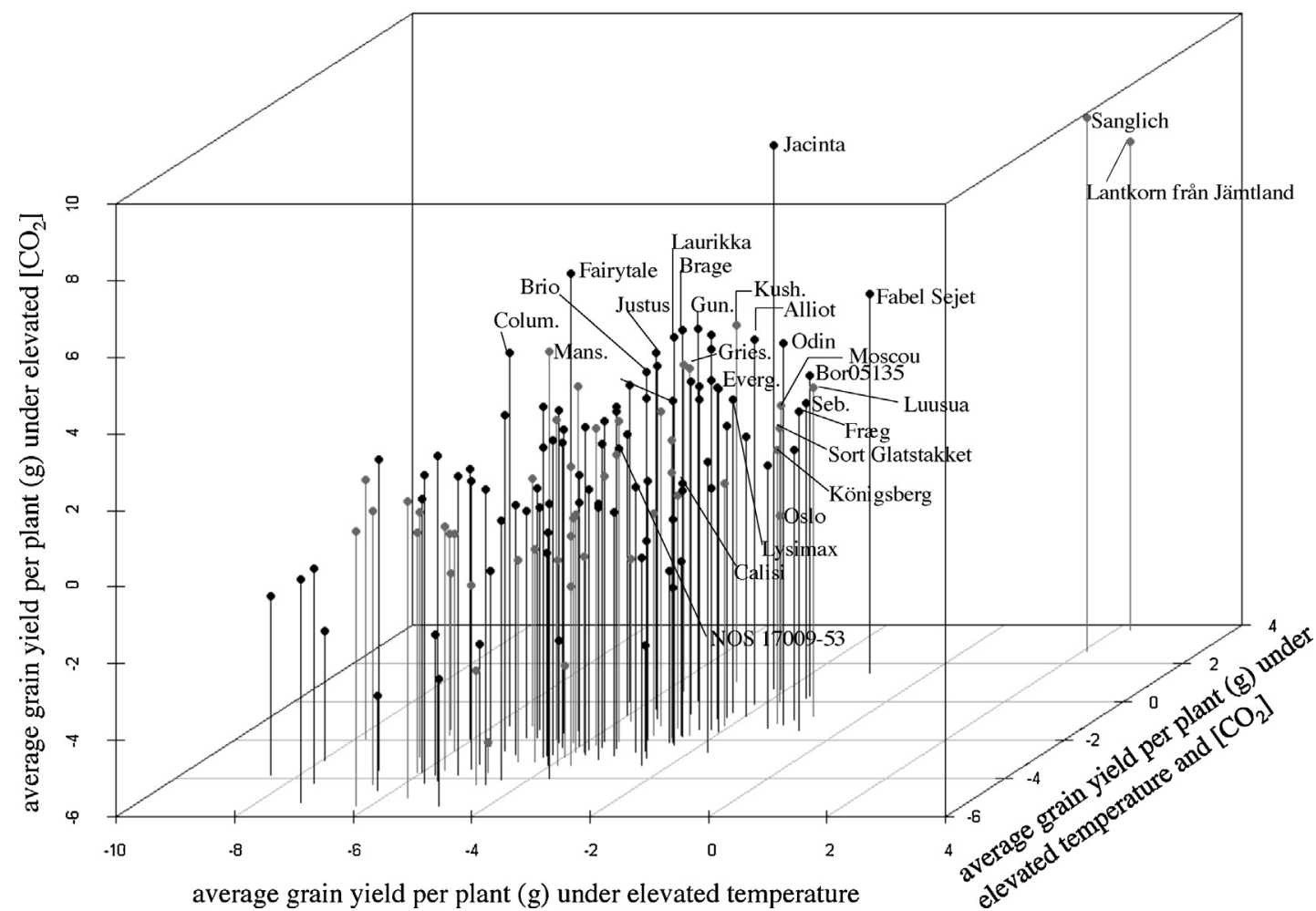

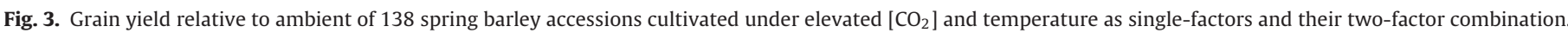

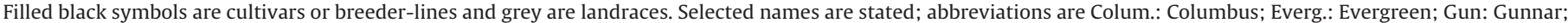
Gries.: Grieschische; Kush.: Kushteki; Mans.: Manschurei; Seb.: Sebastian.

Variation in grain yield to elevated $\left[\mathrm{O}_{3}\right]$ was found within the group of landraces, old and modern cultivars as well as breederlines (Fig. 4). The group of landraces apparently showed the largest

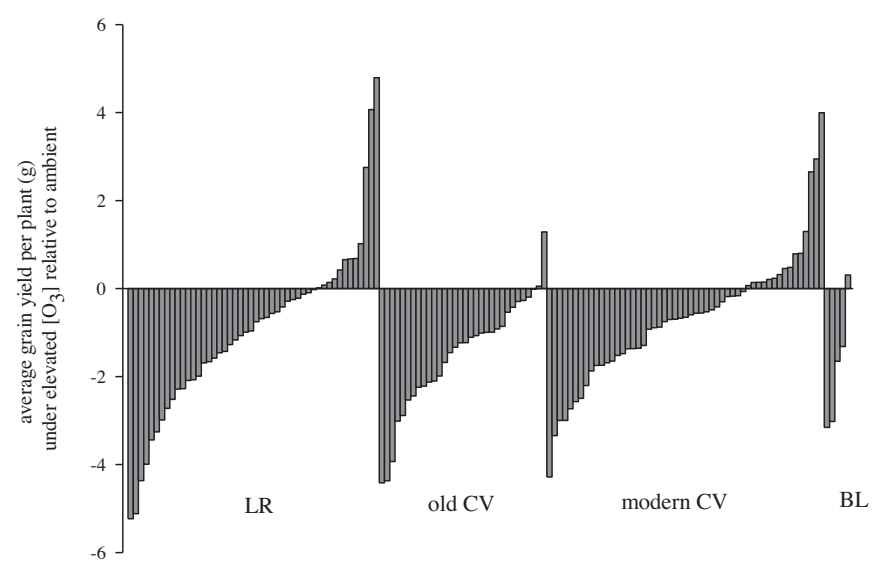

Fig. 4. Grain yield relative to ambient ( 0 ) of 138 spring barley accessions cultivated under elevated $\left[\mathrm{O}_{3}\right]$. LR: landraces, old CV: cultivars from 1883 to 1974, modern CV: cultivars from 1978 to 2013 and BL: breeder-lines. variation in grain yield relative to ambient under elevated $\left[\mathrm{O}_{3}\right]$. Two old cultivars and a Finish landrace, 'Agneta', 'Juli Abed' and 'Ylenjoki', increased grain yield under elevated $\left[\mathrm{O}_{3}\right]$.

\subsection{Trends in stability of grain yield}

Among the 40 accessions with the highest averaged mean grain yield across treatments $\left(m_{i}\right)$, both old and modern cultivars as well as landraces and a breeder-line were found (Table 3 ). The 40 accessions revealed very different scores for static environmental variance $\left(S^{2}\right)$ and dynamic Wricke's ecovalence $\left(W^{2}\right)$. In the set of 138 accessions $S^{2}$ for grain yield spanned from 0.58 to 16.79 and $W^{2}$ from 0.27 to 33.60 , where low values indicate stability over environments (Appendix C). The cultivar 'Sebastian' was static stable and high yielding, ranking 11 th for $S^{2}$ and 4 th for average mean grain yield across treatments. Furthermore, 'Sebastian' ranked 9th for grain yield relative to ambient in the two-factor treatment. The lowest $S^{2}$ in Table 3, was found for 'Åsa' (ranked 8th of the 138 accessions), however, $m_{i}$ of 'Åsa' ranked 40th.

The cultivars 'Agneta', 'Jacinta', and 'Laurikka' were found to differ from the general response of the accessions in at least one of the treatments identified by a high $W^{2}$ score; 'Agneta' and 'Jacinta' ranked first and second according to $m_{i}$. Cultivars identified to be 
Table 3

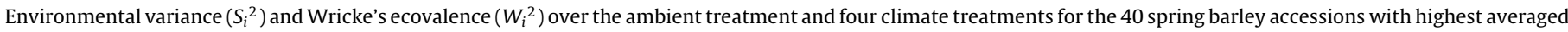
mean yield across treatments $\left(m_{i}\right)$; rank given in ().

\begin{tabular}{|c|c|c|c|c|c|c|c|c|}
\hline Accession name & NGB no. & Culton type & Year of registration & $m_{i}$ & $S_{i}{ }^{2}$ & & $W_{i}^{2}$ & \\
\hline Agneta & NGB1508 & $\mathrm{CV}$ & 1978 & 7.8 & 7.4 & (113) & 20.0 & (134) \\
\hline Jacinta & NGB16665 & $\mathrm{CV}$ & 1999 & 7.7 & 16.8 & (138) & 33.6 & (138) \\
\hline Linus & NGB13482 & $\mathrm{CV}$ & 1997 & 7.5 & 7.4 & $(112)$ & 4.7 & (72) \\
\hline Sebastian & & $\mathrm{CV}$ & 2002 & 7.4 & 1.4 & $(11)$ & 4.3 & (62) \\
\hline Laurikka & & $\mathrm{CV}$ & 2012 & 7.3 & 8.6 & $(122)$ & 10.8 & (116) \\
\hline Paavo & NGB13661 & $\mathrm{CV}$ & 1959 & 7.2 & 5.7 & $(90)$ & 3.0 & (40) \\
\hline Griechische & NGB9333 & LR & & 7.1 & 5.1 & $(80)$ & 4.4 & (65) \\
\hline Odin & NGB16755 & $\mathrm{CV}$ & 1981 & 7.1 & 4.4 & (65) & 5.9 & (90) \\
\hline Stange & NGB2109 & $\mathrm{CV}$ & 1978 & 7.1 & 7.4 & (111) & 3.7 & (51) \\
\hline Evergreen & & $\mathrm{CV}$ & 2010 & 7.0 & 3.9 & $(52)$ & 2.6 & (37) \\
\hline Columbus & & $\mathrm{CV}$ & 2009 & 7.0 & 11.6 & (132) & 10.8 & (115) \\
\hline Brio & NGB9327 & $\mathrm{CV}$ & 1924 & 7.0 & 6.1 & (95) & 5.8 & (87) \\
\hline Gaute & NGB16732 & $\mathrm{CV}$ & 2000 & 7.0 & 6.3 & $(102)$ & 2.2 & (28) \\
\hline Manschurei & NGB9624 & LR & & 7.0 & 12.0 & (136) & 13.5 & (127) \\
\hline Amalika & & $\mathrm{CV}$ & 2012 & 6.9 & 4.9 & $(75)$ & 5.6 & (83) \\
\hline Iron & & $\mathrm{CV}$ & 2007 & 6.9 & 3.4 & $(42)$ & 1.7 & (19) \\
\hline Alliot & NGB16757 & $\mathrm{CV}$ & 1999 & 6.9 & 4.3 & (63) & 4.0 & (54) \\
\hline Szeged & NGB9478 & LR & & 6.8 & 4.3 & (61) & 4.8 & (79) \\
\hline Danpro & NGB9659 & $\mathrm{CV}$ & 1969 & 6.8 & 11.6 & (133) & 9.3 & (110) \\
\hline Orthega & & $\mathrm{CV}$ & 1997 & 6.8 & 11.2 & (131) & 11.0 & (117) \\
\hline Caruso & NGB15059 & $\mathrm{CV}$ & 1991 & 6.8 & 3.9 & $(51)$ & 0.9 & (6) \\
\hline Møyjar & NGB2106 & $\mathrm{CV}$ & 1969 & 6.8 & 8.2 & (116) & 4.4 & (63) \\
\hline Brage & & $\mathrm{CV}$ & 2010 & 6.7 & 6.5 & $(106)$ & 4.7 & (73) \\
\hline Bjørne & NGB9326 & LR & & 6.6 & 6.8 & (107) & 3.6 & (49) \\
\hline Freja & NGB1485 & $\mathrm{CV}$ & 1941 & 6.6 & 4.8 & $(72)$ & 11.8 & $(120)$ \\
\hline Hannuksela & NGB325 & LR & & 6.6 & 5.8 & $(92)$ & 3.0 & $(42)$ \\
\hline Prominant & NGB15066 & $\mathrm{CV}$ & 1999 & 6.5 & 6.4 & (104) & 5.9 & (88) \\
\hline Bor09801 & & $\mathrm{BL}$ & & 6.5 & 2.8 & $(30)$ & 13.9 & (129) \\
\hline Peruvian & NGB8880 & LR & & 6.5 & 3.4 & $(40)$ & 1.7 & (18) \\
\hline Birka & NGB4712 & $\mathrm{CV}$ & 1981 & 6.5 & 4.7 & (69) & 1.6 & (15) \\
\hline Kushteki & NGB6288 & LR & & 6.5 & 5.3 & $(83)$ & 5.8 & (86) \\
\hline Sarkalahti & NGB27 & LR & & 6.4 & 9.9 & (127) & 7.5 & (102) \\
\hline Lysimax & NGB15055 & $\mathrm{CV}$ & 1994 & 6.4 & 2.8 & $(28)$ & 2.0 & (25) \\
\hline Trekker & & $\mathrm{CV}$ & 2013 & 6.4 & 1.4 & (12) & 4.2 & (59) \\
\hline Grenoble I & NGB9378 & LR & & 6.4 & 4.2 & (59) & 1.5 & (13) \\
\hline Metz & NGB9373 & LR & & 6.3 & 2.0 & (17) & 8.5 & (107) \\
\hline Prestige & NGB16750 & $\mathrm{CV}$ & 2000 & 6.3 & 3.7 & $(48)$ & 1.6 & (14) \\
\hline Cicero & NGB16756 & $\mathrm{CV}$ & 1999 & 6.3 & 8.0 & (115) & 4.5 & (67) \\
\hline Pavia & NGB9501 & LR & & 6.2 & 8.2 & (119) & 8.0 & (104) \\
\hline Åsa & NGB4640 & $\mathrm{CV}$ & 1949 & 6.2 & 1.2 & (8) & 8.8 & (108) \\
\hline
\end{tabular}

CV: cultivar; BL: breeder-line; LR: landrace.

static stable according to $S^{2}$ but with low mean grain yield were e.g., 'Moscou', 'Calisi', 'Oslo', and 'Sort Glatstakket' (Appendix C).

\section{Discussion}

Breeding cultivars, which can meet the increased demands for food and feed in the future, is jeopardized by the numerous unknowns of climate change and the lacking characterization of accessions under such conditions. Some of the unknowns are the speed of climate change, the frequency of extreme weather events and whether sufficient genetic resources are available. Modeling studies and selection experiments indicate that naturally occurring microevolution of crops is likely to be overrun by climate change (Alemayehu et al., 2014; Rosenzweig and Parry, 1994; Svenning and Sandel, 2013). With possible little help from microevolution, it is crucial to identify accessions that can serve in breeding high and stable yielding cultivars under climate change conditions.

\subsection{Climate change effects on the barley production}

Published studies on crop production under climate change from enclosure, open-top or free-air carbon enriched (FACE) experiments often included only one or few cultivars. This study encompassed a set of 138 diverse spring barley accessions, and the overall trends identified in response to the applied factors can therefore be considered robust for spring barley.
The strongly decreased grain yield identified under elevated temperature (Fig. 2) is supported by earlier findings (Alemayehu et al., 2014; Clausen et al., 2011; Högy et al., 2013). Most likely, the decreased grain yield is caused by concerted elevated temperature and water shortage leading to oxidative and osmotic stress. Treatments including elevated temperature likely experience greater vapor pressure deficit and increased demand for water uptake possibly leading to drought stress (Barnabás et al., 2008; Powell et al., 2012). Additionally, in a pot setup, as in the present study, soil temperature approximates air temperature, which further increased evaporation of soil water.

The identified positive response in grain yield to elevated $\left[\mathrm{CO}_{2}\right]$ was lower for the large barley set of this study than previously reported for fewer accessions in enclosure studies (Alemayehu et al., 2014; Clausen et al., 2011; Kimball, 1986), but in agreement with the FACE study of Weigel and Manderscheid (2012) on one cultivar of winter barley in a rotation system. These results indicate the importance of analyzing a representative set of accessions to be able to provide solid, general results. The positive effect of elevated $\left[\mathrm{CO}_{2}\right]$ on primary photosynthesis leading to increased grain yield is well established (Ainsworth and Rogers, 2007).

In the two-factor treatment, an additive effect of elevated $\left[\mathrm{CO}_{2}\right]$ and temperature was found to be significantly incompatible with our data. Our findings are supported by indications from previous studies on one cultivar of wheat (Hakala, 1998) and four cultivars of barley (Clausen et al., 2011). As the effect of the sin- 
gle factors temperature and $\left[\mathrm{CO}_{2}\right]$ were not found additive in their combined treatment, we argue that response in complex environments cannot easily be depicted from single factor scenarios. In the present study the effects in the two-factor scenario would have been overestimated from results of the single-factor treatments. When searching for genetic resources exploitable for production under future climate scenarios, where numerous abiotic factors are in play, it must be considered, how the results from screens performed under single-factor treatments can be used. It might even be questioned, if the traditional set up of testing for tolerance to single factors is worth the investment, when resources for use in breeding is the aim.

In the treatments including constantly elevated temperature as single-factor or combined with elevated $\left[\mathrm{CO}_{2}\right]$, the total number of ears increased, whereas number of grains decreased. The impaired grain formation can be caused by elevated temperature disturbing several developmental steps throughout the lifecycle of the plant. Heat exposure prior to anthesis has previously been found to reduce the number of florets and subsequently the number of grains, whereas heat exposure at anthesis aborts the florets at the primordial stage. During the grain filling stage, grain weight and also size is defined, and heat exposure has been found to decrease both (Rajala et al., 2011; Ugarte et al., 2007). To maintain grain yield under elevated temperature breeding for early heading could potentially secure a sufficient period for grain filling, as it is suggested in wheat (Tewolde et al., 2006).

The 138 barley accessions were exposed to a constantly high $\left[\mathrm{O}_{3}\right]$ due to previously reported high $\mathrm{O}_{3}$-tolerance in barley, e.g., spring barley was found to tolerate a 25 times higher dose than wheat (Mills et al., 2007). Our findings indicate a relative higher sensitivity to $\left[\mathrm{O}_{3}\right]$ than reported by Mills et al., 2007 however, it must be kept in mind that no measurements have been performed on $\mathrm{O}_{3}$ taken up by the accessions. Ozone was applied constantly, which can have caused acclimatisation with nearly closed stomata and activation of repair mechanisms.

\subsection{Productivity in cultivars and landraces}

Considering that breeding for decades has aimed at increased grain yield, it is surprising that the group of cultivars only at elevated $\left[\mathrm{CO}_{2}\right]$ produced a higher grain yield than the group of landraces. It has been hypothesized that enhanced net-photosynthesis to elevated $\left[\mathrm{CO}_{2}\right]$ unconsciously has been targeted through breeding. In support of this hypothesis the group of cultivars outperformed the group of landraces in regard to grain yield under increased $\left[\mathrm{CO}_{2}\right]$ as single factor. Though, the effect of increased $\left[\mathrm{CO}_{2}\right]$ was not found for aboveground vegetative biomass, why the higher grain yield in the cultivars might be from improved reallocation during grain filling. However, in the cultivar-group we found a borderline correlation $(p=0.46)$ between year of cultivar registration at the official variety list and grain yield under elevated $\left[\mathrm{CO}_{2}\right]$ indicating that enhanced net-photosynthesis to elevated $\left[\mathrm{CO}_{2}\right]$ has unconsciously been targeted through breeding or by spontaneous year to year adaptation. This finding is contrary to results from previous studies of six barley cultivars (Manderscheid and Weigel, 1997) and four wheat cultivars (Ziska et al., 2004) where no correlation was found. These authors suggested $\mathrm{CO}_{2}$-responsivenes to have potential in breeding. We found that a spontaneous or an unconscious selection to the rising $\left[\mathrm{CO}_{2}\right]$ is already present, however, it is possible that additional increase in grain yield could be achieved with a more targeted selection of cultivars with high $\mathrm{CO}_{2}$ resonsivenes.

With regard to amount of ears produced, the group of cultivars consistently produced more ears than landraces under all singlefactor treatments (Table 2). Hence, the physiological aptitude for increased grain yield in cultivars is present, but grain yield was only higher under elevated $\left[\mathrm{CO}_{2}\right]$. In the two-factor treatment, which was the most realistic future climate scenario, the group of cultivars and group of landraces produced similar amount of ears. Therefore, it seems equally meaningful to search for genetic resources for future environments among old as well as modern accessions.

\subsection{Identification of high yielding and stable accessions}

The accessions with high grain yield and stability were found among landraces as well as cultivars, and they originated in different countries indicating that suitable resources for climate resilience are available from diverse sources. The Danish cultivar 'Sebastian' had high grain yield both under elevated temperature and elevated temperature in combination with elevated $\left[\mathrm{CO}_{2}\right]$ as well as it possessed high $S^{2}$ for grain yield. This is in agreement with 'Sebastian' presently being used in very diverse climates spanning from Ukraine through south-western Europe and Chile. Further, 'Sebastian' has through breeding given rise to the successful cultivar 'Quench', which also demonstrates broad environmental adaptation and high yield (R. Hjortshøj, Sejet Plant Breeding, pers. comm.). The combination of such high static stability and high yield was not found in other of the tested accessions under the conditions of the present experiment, but many accessions with traits promising for high grain yield under future climate conditions were identified. All of the modern cultivars 'Alliot', 'Brage', 'Fairytale', 'Gunnar', and 'Jacinta' showed high yield under the two-factor treatment possible as an effect of high $\mathrm{CO}_{2}$-response (Fig. 3). This suggests that breeding for exploitation of increased $\left[\mathrm{CO}_{2}\right]$ might have potential. The landrace 'Sort Glatstakket' was high yielding in both of the treatments with elevated temperature and therefore possibly holding resources for improvement of heat and/or drought tolerance.

Stability is often found in accessions with a low average grain yield (Becker and Leon, 1988; Powell et al., 2012) as for 'Calisi', 'Moscou', and 'Oslo' in the present study. Interesting though, these three accessions, one modern cultivar and two landraces, showed high yields in the two-factor treatment but not in the ambient treatment, indicating that the response under future conditions cannot be depicted from the current status. When the aim is to breed for stable and high yielding cultivars one approach could be to test if traits for high climate stability could be crossed into high yielding cultivars, for example it might be worth analyzing the backcross offspring from a cross between 'Oslo' with high $S^{2}$ and 'Jacinta' with high $\mathrm{CO}_{2}$-response and high yield in the two-factor treatment. Stability has traditionally been emphasized in subsistence farming as local stability is crucial for survival (Sinebo, 2005; Annicchiarico, 2002). However, with climate change progressing fast, we can within a relatively short timeframe face situations, where our elite cultivars have lost local stability. Here static $S^{2}$ and dynamic $W^{2}$ of a high number of accessions grown under expected future abiotic conditions are reported for the first time (Table 3 , Appendix C), and as we found that the combination of high stability and high yield is infrequent, we argue that both grain yield and climate stability should be targeted in breeding. The drawback of using landraces such as 'Oslo' or 'Sort Glatstakket' in breeding programmes is the risk of transferring unwanted genetic material, and disturbing established allele complexes in the optimized germplasm. Nevertheless, introduction of germplasm from exotic accessions can be advantageous in widening the genetic base of crops (Brantestam et al., 2007; Malysheva-Otto et al., 2007; Russell et al., 2000) as traditionally performed in breeding for disease resistance. Here traits have successfully been transferred to elite cultivars to achieve resistance (Colton et al., 2006; Czembor, 2000; Silvar et al., 2013). 


\subsection{Challenges in the identification of plant resources for future climate conditions}

In almost all cases screening of plant accessions for response to future climate conditions has to be performed in manipulated settings, and the outcome will be a result of the applied conditions. To which extent results obtained under manipulated conditions will agree with results from field conditions with natural root development and plant-disease interactions is uncertain. Despite the large phytotron chambers $\left(24 \mathrm{~m}^{2}\right)$ used in the present study, the authors acknowledge that the environment within the RERAF phytotron with constant temperature, no clouds, pot set up and limited biotic stress is non-natural. Also, results are given relative to an ambient treatment that for some accessions might be far from their normal ambient environment. Experiments in FACE facilities are more natural, however, the methods for increasing temperature e.g., by roof or infrared reflectance technology has to this day not proven capable of elevating temperature regimes with more than $2-3^{\circ} \mathrm{C}$ or has resulted in asymmetric warming (e.g., Bruhn et al., 2013; Kimball et al., 2008).

\section{Conclusion}

For the first time a comprehensive set of 138 spring barley accessions has been cultivated in their entire life cycle under a twofactor climate scenario of elevated $\left[\mathrm{CO}_{2}\right]$ and temperature. Further, static and dynamic stability of grain yield over the two-factor treatment, and three single-factor treatments as well as an ambient treatment were reported. We found substantial variation among individual accessions under all applied treatments. A considerable decreased grain yield of $29 \%$ in the two-factor climate scenario was found, and a mixed effects model confirmed that results in this combined scenario could not be predicted from results of its single-factor treatments. This finding emphasizes the need for phenotyping accessions under realistic multifactor climate conditions, as single-factor experiments might provide limited or even misleading information to the forecasting of effects. Further, we have identified potential genetic resources with regard to production performance and stability under future climate conditions. These genetic resources could and should be exploited in breeding programmes.

\section{Acknowledgements}

We thank the technical staff at DTU-KT, ECO-Risø for help throughout cultivation and harvest procedures. A special thanks to Rene H. Petersen for threshing the 5600 individual plants. Thanks to Allan Murphy and Esben Højrup for technical assistance in RERAF. Cathrine $\mathrm{H}$. Ingvordsen was funded by the Nordic Council of Ministers as a member of the network, 'Sustainable primary production in a changing climate'. COBRA (Core Organic II) granted funding for parts of the experiments. The $\mathrm{CO}_{2}$ used in this study was generously supplied by Air Liquide Denmark A/S.

\section{Appendix A. Supplementary data}

Supplementary data associated with this article can be found, in the online version, at http://dx.doi.org/10.1016/j.eja.2014.12.003.

\section{References}

Ainsworth, E.A., Rogers, A., 2007. The response of photosynthesis and stomatal conductance to rising $\left[\mathrm{CO}_{2}\right]$ : mechanisms and environmental interactions. Plant Cell Environ. 30, 258-270.

Alemayehu, F.R., Frenck, G., Van der Linden, L., Mikkelsen, T.N., Jørgensen, R.B., 2014. Can barley (Hordeum vulgare L. s. l.) adapt to fast climate changes? A controlled selection experiment. Genet. Resource Crop Evol. 61, 151-161.
Annicchiarico, P., 2002. Genotype x Environment Interactions - Challenges and Opportunities for Plant Breeding and Cultivar Recommendations. FAO Plant Production and Protection Paper 174. FAO, Rome.

Anwar, M.R., Liu, D.L., Macadam, I., Kelly, G., 2013. Adapting agriculture to climate change: a review. Theor. Appl. Climatol. 113, 225-245.

Barnabás, B., Jäger, K., Fehér, A., 2008. The effect of drought and heat stress on reproductive processes in cereals. Plant Cell Environ. 31, 11-38.

Becker, H.C., Leon, J., 1988. Stability analysis in plant breeding. Plant Breeding 101 $1-23$.

Brantestam, A.K., von Bothmer, R., Dayteg, C., Rashal, I., Tuvesson, S., Weibull, J., 2007. Genetic diversity changes and relationships in spring barley (Hordeum vulgare L.) germplasm of Nordic and Baltic areas as shown by SSR markers. Genet. Resource Crop Evol. 54, 749-758.

Bruhn, D., Larsen, K.S., de Dato, G.D., Duce, P., Zara, P., Beier, C., Schmidt, I., Clausen, K., Mikkelsen, S., 2013. Improving the performance of infrared reflective night curtains for warming field plots. Agric. For. Meteorol. 73, 53-62.

Ceccarelli, S., Grando, S., Maatougui, M., Michael, M., Slash, M., Haghparast, R., Rahmanian, M., Taheri, A., Al-Yassin, A., Benbelkacem, A., Labdi, M., Mimoun, H., Nachit, M., 2010. Plant breeding and climate changes. J. Agric. Sci. 148, 627-637.

Christensen, O.B., Goodess, C.M., Harris, I., Watkiss, P., 2011. European and global climate change projections: discussion of climate change model outputs, scenarios and uncertainty in the ec rtd climatecost project. In: Watkiss, P. (Ed.) The ClimateCost Project. Final Report. Europe, Volume 1. Published by the Stockholm Environment Institute, Sweden, ISBN 978-91-86125-35-6.

Clausen, S.K., Frenck, G., Linden, L.G., Mikkelsen, T.N., Lunde, C., Jørgensen, R.B., 2011. Effects of single and multifactor treatments with elevated temperature, $\mathrm{CO}_{2}$ and ozone on oilseed rape and barley. J. Agron. Crop Sci. 197, 442-453.

Collins, M., Knutti, R., Arblaster, J., Dufresne, J.-L., et al., 2013. In: Stocker, T.F., Qin, D., Plattner, G.-K., Tignor, M., Allen, S.K., Boschung, J., Nauels, A., Xia, Y., Bex, V., Midgley, P.M. (Eds.), Long-term Climate Change: Projections, Commitments and Irreversibility. In: Climate Change 2013: The Physical Science Basis. Contribution of Working Group I to the Fifth Assessment Report of the Intergovernmental Panel on Climate Change. Cambridge University Press, Cambridge, United Kingdom and New York, NY, USA.

Colton, L.M., Groza, H.I., Wielgus, S.M., Jiang, J., 2006. Marker-assisted selection for the broad-spectrum potato late blight resistance conferred by gene rb derived from a wild potato species. Crop Sci. 46, 589-594.

Craufurd, P.Q., Hauser, I.E., Dingkuhn, M., 2003. Phototermal responses of O. sativa and 0 . glaberrima varieties and interspecific progenies from west Africa. Field Crop. Res. 83, 313-324.

Czembor, J.Z., 2000. Resistance to powdery mildew in populations of barley landraces from Morocco. Genet. Resource Crop Evol. 47, 439-449.

Ellermann, T., Nøjgaard, J.K., Nordstrøm, C., Brandt, J., Christensen, J., Ketzel, M., Jansen, S., Massling, A., Jensen, S.S., The Danish Air Quality Monitoring Programme. Annual Summary for 2012. Aarhus University, DCE-Danish Centre for Environment and Energy. 59 pp. Scientific Report from DCE - Danish Centre for Environment and Energy. No. 67; 2013 Available at: http://dce2.au.dk/pub/SR67.pdf

European Union, Short Term Outlook for EU arable crops, dairy and meat markets in 2014 and 2015. 2014, Autumn 2014. Available at: http://ec.europa.eu/agriculture/markets-and-prices/short-term-outlook/pdf 2014-10 en pdf

FAOSTAT, Food Supply, Crops Primary Equivalent 2014; http://faostat3fao.org/faostat-gateway/go/to/home/E, [cited January 2014]

Feng, Z., Kobayashi, K., 2009. Assessing the impacts of current and future concentrations of surface ozone on crop yield with meta-analysis. Atmos. Environ. 43, 1510-1519.

Foley, J.A., Ramankutty, N., Brauman, K.A., Cassidy, E.S., Gerber, J.S., Johnston, M., Mueller, N.D., O'Connell, C., Ray, D.K., West, P.C., Balzer, C., Bennett, E.M., Carpenter, S.R., Hill, J., Monfreda, C., Polasky, S., Rockström, J., Sheehan, J., Siebert, S., Tilman, D., Zaks, D.P.M., 2011. Solutions for a cultivated planet. Nature 478, 337-342.

Frenck, G., van der Linden, L., Mikkelsen, T.N., Brix, H., Jørgensen, R.B., 2011. Increased $\left[\mathrm{CO}_{2}\right]$ does not compensate for negative effects on yield caused by higher temperature and $\left[\mathrm{O}_{3}\right]$ in Brassica napus L. Eur. J. Agron. 35, 127-134.

Fuhrer, J., Booker, F., 2003. Ecological issues related to ozone: agricultural issues. Environ. Int. 29, 141-154

Fuhrer, J., Skärby, L., Ashmore, M.R., 1997. Critical levels for ozone effects on vegetation in Europe. Environ. Pollut. 97, 91-106.

Hakala, K., 1998. Growth and yield potential of spring wheat in a simulated changed climate with increased $\mathrm{CO}_{2}$ and higher temperature. Eur. J. Argon. 9 41-52.

Högy, P., Poll, C., Marhan, S., Kandeler, E., Fangmeier, A., 2013. Impacts of temperature increase and change in precipitation pattern on crop yield and yield quality of barley. Food Chem. 136, 1470-1477.

IPCC, Summary for Policymakers; Climate Change 2014, Impacts, Adaptation, and Vulnerability. Contribution of Working Group II to the Fifth Assessment Report of the Intergovernmental Panel on Climate Change, 2014; 1-44.

Juknys, R., Duchovskis, P., Sliesaravičius, A., Šlepetys, J., Januškaitienè, I., Brazaityetè, A., Ramaškevičienè, A., Lazauskas, S., Dėdelienė, K., Sakalauskaitè, J., Juozaitytė, R., Kadžiulirnè Ž, Dikšaitytè, A., 2011. Response of different agricultural plants to elevated $\mathrm{CO}_{2}$ and air temperature. Žemdirbystè-Agriculture 98, 259-266.

Kasurinen, A., Biasi, C., Holopainen, T., Rousi, M., Mäenpää, M., Oksanen, E., 2012. Interactive effects of elevated ozone and temperature on carbon allocation of 
silver birch (Betula pendula) genotypes in an open-air field exposure. Tree Physiol. 32, 737-751.

Kimball, B.A., 1986. In: Enoch, H.Z., Kimball, B.A. (Eds.), Influence on Elevated $\mathrm{CO}_{2}$ on Crop Yield. In: Carbon Dioxcide Enrichment of Greenhouse Crops Volume II Physiology, Yield and Economics. CRC Press Inc, USA.

Kimball, B.A., Conley, M.M., Wang, S., Lin, X., Luo, C., Morgan, J., Smith, D., 2008. Infrared heater arrays for warming ecosystem field plots. Glob. Change Biol. 14, 309-320.

Lobell, D.B., Field, C.B., 2007. Global scale climate-crop yield relationships and the impacts of recent warming. Environ. Res. Lett. 2, 1-7.

Lobell, D.B., Schlenker, W., Costa-Roberts, J., 2011. Climate trends and global crop production since 1980 . Science 333, 616-620.

Long, S.P., Zhu, X.-G., Naidu, S.L., Ort, D.R., 2006. Can improvement in photosynthesis increase crop yields? Plant Cell Environ. 29, 315-330.

Luo, Q., 2011. Temperature thresholds and crop production: a review. Clim. Change 109, 583-598.

Malysheva-Otto, L., Ganal, M.W., Law, J.R., Reeves, J.C., Röder, M.S., 2007. Tempora trends of genetic diversity in European barley cultivars (Hordeum vulgare L.) Mol. Breeding 20, 309-322.

Manderscheid, R., Weigel, H.-J., 1997. Photosynthetic and growth responses of old and modern spring wheat cultivars to atmospheric $\mathrm{CO}_{2}$ enrichment. Agric. Ecosyst. Environ. 64, 65-73.

Mills, G., Buse, A., Gimeno, B., Bermejo, V., Holland, M., Embersond, L., Pleijel, H., 2007. A synthesis of AOT40-based response functions and critical levels of ozone for agricultural and horticultural crops. Atmos. Environ. 41, 2630-2643.

Mitchell, R.A., Mitchell, V.J., Driscoll, S.P., Franklin, J., Lawlor, D.W., 1993. Effects of increased $\mathrm{CO}_{2}$ concentration and temperature on growth and yield of winter wheat at two levels of nitrogen application. Plant Cell Environ. 16, 521-529.

Mora, C., Fraizier, A.G., Longman, R.J., Dacks, R.S., Walton, M.M., Tong, E.J., Sanchez, J.J., Kaiser, L.R., Stender, Y.O., Anderson, J.M., Ambrosino, C.M., Fernandez-Silva, I., Giuseffi, L.M., Giambelluca, T.W., 2013. The projected timing of climate departure from recent variability. Nature 502, 183-188.

Newton, A.C., Johnson, S.N., Gregory, P.J., 2011. Implications of climate change for diseases, crop yields and food security. Euphytica 179, 3-18.

OECD/FAO, OECD - Food and Agriculture Organization of the United Nations Agricultural Outlook 2013 OECD Publishing 2013; Available at: 10.1787/agr_outlook-2013-en

Pleijel, H., 2011. Reduced ozone by air filtration consistently improved grain yield in wheat. Environ. Pollut. 159, 897-902.

Powell, N., Ji, X., Ravash, R., Edlington, J., Dolferus, R., 2012. Yield stability for cereals in a changing climate. Funct. Plant Biol. 39, 539-552.

Rajala, A., Hakala, K., Mäkelä, P., Peltonen-Sainio, P., 2011. Drought effects on grain number and grain weight at spike and spikelet level in six-row spring barley. J. Agron. Crop Sci. 197, 103-112.

R Core Team, R: A Language and Environment for Statistical Computing R Foundation for Statistical Computing Vienna, Austria 2014; http://www.R-project.org/

Roemer, T., 1917. Sind die ertragsreichen Sorten ertragssicherer? Mitteilung Deutsche Landwirtschafts-Gesellschaft, 32, 87-89.
Rosenzweig, C., Parry, M.L., 1994. Potential impact of climate change on world food supply. Nature 367, 133-138.

Russell, J.R., Ellis, R.P., Thomas, W.T.B., Waugh, R., Provan, J., Booth, A., Fuller, J., Lawrence, P., Young, G., Powell, W., 2000. A retrospective analysis of spring barley germplasm development from 'foundation genotypes' to currently successful cultivars. Mol. Breeding 6, 553-568.

Sherwood, S.C., Bony, S., Dufresne, J.-L., 2014. Spread in model climate sensitivity traced to atmospheric convective mixing. Nature 505, 37-42.

Silvar, C., Kopahnke, D., Flath, K., Serfling, A., Perovic, D., Casas, A.M., Igartua, E., Ordon, F., 2013. Resistance to powdery mildew in one Spanish barley landrace hardly resembles other previously identified wild barley resistances. Eur. J. Plant Pathol. 136, 459-468.

Sinebo, W., 2005. Trade off between yield increase and yield stability in three decades of barley breeding in a tropical highland environment. Field Crop Res. $92,35-52$.

Svenning, J.-C., Sandel, B., 2013. Disequilibrium vegetation dynamics under future climate change. Am. J. Bot. 100, 1266-1286.

Tewolde, H., Fernandez, C.J., Erickson, C.A., 2006. Wheat cultivars adapted to post-heading high temperatures. J. Agron. Crop Sci. 192, 111-120.

Trnka, M., Brázdil, R., Olesen, J.E., Eitzinger, J., Zahradníček, P., Kocmánková, E., Dobrovolný, P., Štěpánek, P., Možný, M., Bartošová, L., Hlavinka, P., Semerádová, D., Valášek, H., Havlíček, M., Horáková, V., Fischer, M., Žalud, Z., 2012. Could the changes in regional crop yields be a pointer of climatic change? Agric. For. Meteorol. 166-167, 62-71.

Ugarte, C., Calderini, D.F., Slafer, G.A., 2007. Grain weight and grain number responsiveness to pre-anthesis temperature in wheat barley and triticale. Field Crop Res. 100, 240-248.

Wei, W., Cheng, S., Li, G., Wang, G., Wang, H., 2014. Characteristics of ozone and ozone precursors (VOCs and $\mathrm{NO}_{x}$ ) around a petroleum refinery in Beijing China. J. Environ. Sci. 26, 332-342.

Weigel, H.-J., Manderscheid, R., 2012. Crop growth responses to free air $\mathrm{CO}_{2}$ enrichment and nitrogen fertilization: rotating barley, ryegrass, sugar beet and wheat. Eur. J. Argon. 43, 97-107.

Wricke, G., 1962. Über eine Methode zur Erfassung der okologischen Streubreite in Feldversuchen. Z. Pflanzenzuchtg. 47, 92-96.

Zhou, X., Ge, Z.-M., Kellomäki, S., Wang, K.-Y., Peltola, H., Martikainen, P., 2011. Effects of elevated $\mathrm{CO}_{2}$ and temperature on leaf characteristics: photosynthesis and carbon storage in aboveground biomass of a boreal bioenergy crop (Phalaris arundinacea L.) under varying water regimes. GCB Bioenergy 3 , 223-234.

Zadoks, J.C., Chang, T.T., Konzak, C.F., 1974. A decimal code for the growth stages of cereals. Weed Res. 14, 415-421.

Ziska, L.H., Morris, C.F., Goins, E.W., 2004. Quantitative and qualitative evaluation of selected wheat varieties released since 1903 to increasing atmospheric carbon dioxide: can yield sensitivity to carbon dioxide be a factor in wheat performance? Global Change Biol. 10, 1810-1819. 